\title{
The Using Boron-containing Materials in Ferroalloy Industry
}

\section{\| Nikolaevich Kel'}

Institute of Metallurgy of the Ural Branch of the Russian Academy of Sciences, Yekaterinburg, Russia

\section{Abstract}

The article presents an analytical review of the use of boron-containing materials in ferrous metallurgy. Literature data are given on the improvement of the properties of steel with the addition of an ultra-small amount of boron. The review presents the main existing technologies for the preparation of boron-containing alloys and their features, as well as methods for introducing boron into steel. In domestic and foreign production, ferroboron has been widely used with $6-20 \%$ B. Due to the high chemical activity, part of the boron transferred to the metal reacts with nitrogen. A number of methods have been proposed in the literature for preventing boron binding. One of them is

Corresponding Author:

I Nikolaevich Kel'

dunnington@mail.ru

Received: 5 February 2019

Accepted: 6 March 2019

Published: 17 March 2019

Publishing services provided by

Knowledge

(ㄷ) I Nikolaevich Kel'. This article is distributed under the terms of the Creative Commons

Attribution License, which permits unrestricted use and redistribution provided that the original author and source are credited

Selection and Peer-review under the responsibility of the NIOKR-2018 Conference Committee. the introduction of boron by complex boron-containing ferroalloys with $1-2 \% \mathrm{~B}$. Using this method increases the degree of transition of boron to metal. The review shows the possibility of wide use of boron-containing materials in the processes of ferrous metallurgy.

Keywords: steel, ferroalloys, metal properties, complex ferroalloy

\section{Introduction}

Boron is being used as a micro-alloying additive due to the favorable effect on the properties of many steel grades. The boron use has a great economic advantage compared to a traditional alloying element using due to the fact that the ultra-low boron concentrations in steel are required to achieve the required properties. However, the need to accurately obtain its concentration in steel and the difficulties associated with the assimilation of the processed metal, restrain the widespread use of boron.

Currently, there are a large number of works that provide data on the use of boron in various fields of metallurgy. The main attention in the literature is given to the properties of a metal doped with boron, as well as its microstructure.

The main forms of boron in steel are oxides, nitrides $(\mathrm{BN})$ and iron borides $\left(\mathrm{Fe}_{2} \mathrm{~B}\right.$ and FeB). Borders of boron content in steel are in the range from 0,0005 to $0,01 \%$. The optimal concentration has to be at $0,001-0,003 \%$ B by opinion of most authors. This 
concentration has a positive effect on the properties of steel [1]. The data on improvement in strength with the introduction of 0,001-0,003\% boron into low-alloyed steel are given in $[2,3]$. The authors associate improvement in strength with the segregation of boron to the grain boundaries of austenite which delays the formation of crystallization centers. It's noted that the improvement of performance properties for carbon steel and for structural steel an increase in workability, fatigue strength and weldability are observed.

The article [4] reports that the effect of the boron microalloying decreases with increasing of carbon content in steel. In the study [3], it is recommended to do deoxidation and degassing of steel for greater efficiency of small boron additives. The dependence of the mechanical properties of steel on the ratio $\mathrm{B} / \mathrm{N}_{\text {tot }}$ associated with the tendency of boron to form nitrides is given (The dependence of the mechanical properties of steel on the ratio $\mathrm{B} / \mathrm{N}_{\text {tot }}$ is given. This dependence is associated with the tendency of boron to form nitrides). Technological aspects of the production of steel and ferroalloys containing boron is poorly examined in literature. Boron is introduced (не уверен что это слово подойдет, быть может что-то вроде injected) into a melt in the form of boron-containing ferroalloys. The most common ferroalloy is ferroboron with a boron content of $6-20 \%$. A typical composition of boron-containing ferroalloys is presented in the table [2].

The main methods for producing boron-containing ferroalloys are carbothermic and metallothermic [4].

TABLE 1: The chemical composition of boron-containing ferroalloys.

\begin{tabular}{|c|c|c|c|c|c|c|c|c|c|c|c|}
\hline \multirow[t]{2}{*}{ Марка } & \multicolumn{11}{|c|}{ Weight percentage, \% } \\
\hline & B & $\mathbf{S i}$ & Al & C & $\mathbf{s}$ & $\mathbf{P}$ & $\mathbf{N i}$ & $\mathrm{Cr}$ & Mn & $\mathbf{T i}$ & $\mathbf{Z r}$ \\
\hline FB20 & 20 & 2 & 3 & 0,05 & 0,01 & 0,02 & - & - & - & - & - \\
\hline FB17 & 17 & 3 & 5 & 0,20 & 0,02 & 0,03 & - & - & - & - & - \\
\hline FB12 & 12 & 10 & 10 & - & - & - & - & - & - & - & - \\
\hline FB6 & 6 & 10 & 10 & - & - & - & - & - & - & - & - \\
\hline NiB-1 & 10,5 & 1,5 & 7 & 0,08 & 0,006 & 0,01 & remains & - & - & - & - \\
\hline $\mathrm{NiB}-2$ & 17 & 1,5 & 7 & 0,17 & 0,015 & 0,03 & remains & - & - & - & - \\
\hline NiB-3 & 10 & 1,5 & 7 & 0,2 & 0,03 & 0,02 & remains & - & - & - & - \\
\hline FeCrB-1 & 19 & 3 & 5 & 0,8 & 0,01 & - & - & 43 & - & - & - \\
\hline FeCrB-2 & 17 & 3 & 6 & 0,6 & 0,02 & - & - & 35 & - & - & - \\
\hline $\begin{array}{l}\text { FeSiMn } \\
\text { with B }\end{array}$ & 0,7 & 15,74 & - & 1,6 & - & - & - & & 68,7 & - & - \\
\hline Grainal & 1 & 6 & 15 & - & - & - & - & - & - & 10 & 15 \\
\hline Alloy CrB & 8 & $<2$ & $<2$ & $<0,1$ & & & & $>85$ & & & \\
\hline
\end{tabular}

The use of the carbothermic method allows to obtain alloys with high carbon content. 
The interaction of carbon and boron oxide is described by the equation [5]:

$$
\frac{2}{3} \mathrm{~B}_{2} \mathrm{O}_{3}+2 \mathrm{C}=\frac{4}{3} \mathrm{~B}+2 \mathrm{CO} \quad \Delta G_{T}^{0}=661890-346,3 T .
$$

According to [2], it is thermodynamically more likely to obtain boron carbides, and not pure boron:

$$
\frac{2}{3} \mathrm{~B}_{2} \mathrm{O}_{3}+7 / 3 \mathrm{C}=\frac{1}{3} \mathrm{~B}_{4} \mathrm{C}+2 \mathrm{CO} \quad \Delta G_{T}^{0}=579350-314,3 T .
$$

The boron carbide is a strong chemical compound, thus the alloy produced by carbothermy will inevitably contain up to $2 \% \mathrm{C}$. It is possible to produce alloys with a low carbon content and a high silicon content (Si 40\%, B 5\%) in the case of simultaneous reduction of boron and silicon.

The refractory borides $\mathrm{TiB} 2$ and $\mathrm{TiB}$ which melting points is at 3100 and $3000^{\circ} \mathrm{C}$ re are formed in boron-titanium alloys. These phases have small density and it leads to distribution of boron by the whole volume of the alloy [6]. One of the promising methods for the production of boron-containing alloys is the SHS method (self-propagating hightemperature synthesis). The data on the use of the SHS method for producing titanium boride containing $8,6-14,5 \% \mathrm{~B}$ is given in $[7,8]$. The resulting alloy is a composition of titanium borides based on iron in the presence of boron, aluminum and residual titanium. In [6], a new technology for obtaining a boron-containing ligature in the combustion mode with a wide range of changes in the $\mathrm{B} / \mathrm{Ti}$ ratio was developed. During burning of mixtures that contains ferrotitanium and ferroboron, it is possible to obtain ferrobortitanium with $6-14 \% \mathrm{~B}$ and $30-60 \% \mathrm{Ti}$.

The aluminothermic method to obtaining boron-containing alloys, including ferroboron $[2,3,9,10]$, which proceeds by the reaction [5], has a wide distribution:

$$
\frac{2}{3} \mathrm{~B}_{2} \mathrm{O}_{3}+\frac{4}{3} \mathrm{Al}=\frac{4}{3} \mathrm{~B}+\frac{2}{3} \mathrm{Al}_{2} \mathrm{O}_{3} \quad \Delta G_{T}^{0}=-294010+68,75 T .
$$

The charge consists of primary aluminum powder (for grades FB20 and FB17) or aluminum shavings, iron oxide or low-phosphorous iron ore and freshly burned lime.

Complex boron-containing ferroalloys are produced in electric furnaces by the furnace aluminothermic method or by the method of metallothermicremelting. Such ferroalloys include chromobor containing, \%: $\geq 8 \mathrm{~V} ; \geq 85 \mathrm{Cr} ; \leq 2 \mathrm{Al} ; \leq 2 \mathrm{Si}$ [1]; grainal with chemical composition,\%: $\geq 1 \mathrm{~V} ; \geq 6,0 \mathrm{Si}$; $\geq 15,0 \mathrm{Al} ; \geq 10,0 \mathrm{Ti} ; \geq 1,5 \mathrm{Zr}$; $\leq 2,0 \mathrm{Mn}$. The grainal is obtained by the method of metallothermicremelting. A part of alloying elements in the form of metals and alloys (the metal part of the mixture) dissolves in the resulting alloy due to the excess amount of heat released during the reduction of the oxide elements contained in the aluminothermic part of the mixture. 
The increased chemical activity of boron in combination with the high temperatures of the processes and the small amount of the alloying element introduced lead to technological difficulties with the methods of introducing boron into steel., cored wire is used to increase the degree of boron assimilation by steel [1]. In order to prevent the interaction of boron in liquid steel with oxygen and nitrogen, the authors [7] proposed to have chemically active elements ( $\mathrm{Si}, \mathrm{Ti}, \mathrm{Al}$, etc.) in all boron-containing ferroalloys. In addition, due to the small amount of boron introduced into steel $(0,001-0,0003 \%)$ in ferroalloy it is advisable to have $0.5-2 \% \mathrm{~B}$, which allows you to increase the mass of the ferroalloy positively affecting the degree of boron uptake.

Silicothermic reduction of boron oxide is impossible without additional heat supply and proceeds by the reaction [5]:

$$
\frac{1}{3} \mathrm{~B}_{2} \mathrm{O}_{3}+\mathrm{Si}=\frac{4}{3} \mathrm{~B}+\mathrm{SiO}_{2} \quad \Delta G_{T}^{0}=-10376+32,36 T .
$$

The Institute of Metallurgy of Ural Branch of the RAS developed a method for producing of complex ferroalloy based on FS65 with a boron content of up to 1\% [11, 12].

The influence of the type of boron-containing material on the degree of boron uptake was evaluated under laboratory conditions [13]. During the experiments 3 types of colemanite was used. The First one was previously melted at $1300^{\circ} \mathrm{C}$, the second was briquetted and calcined at $600^{\circ} \mathrm{C}$, the third (in the form of colemanite powder) was calcined. Than these boron materials was added to a liquid ferrosilicon melt. As a result of the research, it was found that the most suitable boron-containing material for obtaining complex ferroalloy is calcined colemanite $\left(\mathrm{B}_{2} \mathrm{O}_{3}\right.$ 49,8\%; $\mathrm{CaO} 32,6 \% ; \mathrm{MgO} 2,19 \%$; $\mathrm{SiO}_{2}$ $15,41 \%)$. This material has a high content of $\mathrm{B}_{2} \mathrm{O}_{3}(\geq 40,0 \%)$, there is no water for crystallization in it, it can be prepared to the desired fractional composition, has the lowest amount of losses during melting.

The influence of the interaction time of colemanite and the reducing agent, the process temperature, the amount and composition of colemanite introduced on the degree of boron uptake by the alloy was found. It is shown that the holding time of the melt at a constant temperature $\left(1650^{\circ} \mathrm{C}\right)$ significantly increases the degree of boron absorption (K). For samples of briquetted colemanite an increase in the holding time of the melt from 5 to 15 minutes increases the degree of boron assimilation from 44.7 to $57.7 \%$. For samples of calcined colemanite powder this degree increases from 48.0 to $71.2 \%$.

One of the applications of boron in ferroalloy production is the stabilization of highly basic slags with $\mathrm{B}_{2} \mathrm{O}_{3}$. The production of low carbon ferrochrome is associated with the formation of highly basic slags $\left(46-52 \% \mathrm{CaO} ; 26-29 \% \mathrm{SiO}_{2} ; 5-7 \% \mathrm{MgO} ; 4-7 \% \mathrm{Al}_{2} \mathrm{O}_{3} ; 3-\right.$ $7 \% \mathrm{Cr}_{2} \mathrm{O}_{3}$ and up to $0,5 \% \mathrm{FeO}$ ). The main mineral phase of the slag is $2 \mathrm{CaO} \cdot \mathrm{SiO}$. This 
orthosilicate is undergoing the $\beta-2 \mathrm{CaO} \cdot \mathrm{SiO}_{2} \rightarrow \gamma-2 \mathrm{CaO} \cdot \mathrm{SiO}_{2}$ polymorphic transformation. The increase of volume of orthosilicate (by 10-12\%) during cooling leads to slag selfdisintegration into a fine fraction. Slag phase composition: $2 \mathrm{CaO} \cdot \mathrm{SiO}_{2}$ (62-76\%); $\mathrm{MgO}$

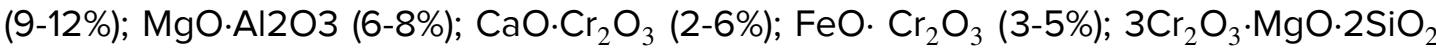
(up to $13 \%$ ) [14].

Treatment by $\mathrm{B} 2 \mathrm{O} 3$ for stabilization of slag was tested. Experiments were performed using a fused colemanite $\left(42,8 \% \mathrm{~B}_{2} \mathrm{O}_{3}\right)$. After entering into the slag more than $0,3 \% \mathrm{~B}_{2} \mathrm{O}_{3}$ a complete stabilization occurs. As a result of industrial tests, it was shown that it is possible in principle to use $\mathrm{B}_{2} \mathrm{O}_{3}$ to stabilize slags as the most efficient and economical method [14].

\section{Conclusion}

Boron is widely used in the ferroalloy industry. The received new ferroalloys can significantly reduce the cost of steel production without deteriorating its consumer properties. In addition to using of boron oxides as an alloying agent they are used to prevent highly basic slags from silicate decomposition.

\section{Acknowledgements}

The research was carried with the help of a grant from the Russian Science Foundation (Project No. 16-19-10435).

\section{References}

[1] Golubtsov V.A. (2006). Theory and practice of introducing additives into steel outside the furnace. Chelyabinsk.

[2] Lyakishev NP, Pliner Yu.L., Lappo S.I. (1986). Boron steels and alloys. Moscow: Metallurgy..

[3] Goldstein Ya.E., Mizin V.G. (1986). Modification and microalloying of iron and steel. Moscow: Metallurgy.

[4] Kasparova O.V. (2013) Influence of boron and carbon on the structure and corrosionelectrochemical behavior of austenitic $\mathrm{X} 2 \mathrm{OH} 20$ stainless steel. Physical chemistry of the surface and protection of materials, vol. 49, no. 6. P. 671

[5] Gasik M.I., Lyakishev NP, Emlin B.I. (1988). Theory and technology of production of ferroalloy. Moscow: Metallurgy. 
[6] Ziatdinov M.Kh. (2016) Development of theoretical and technological foundations of self-propagating high-temperature synthesis in the development of industrial technology for the production of materials for steelmaking and blast-furnace production. PhD dissertation/Master's thesis. State university of Tomsk.

[7] Manashev I.R., Shatokhin I.M., Ziatdinov M.Kh. et al. (2009). Features of microalloying with boron and new material boride ferrotitanium. Steel, no. 10. PP. 34-38.

[8] Maksimov Yu.M., Chukhlomina L.N., Braverman B.Sh., Smirnov L.A. (2002). Selfpropagating high-temperature synthesis of nitrogen-containing alloys for metallurgy. Novosibirsk: Science.

[9] Pliner Yu.L. (1963). Aluminothermic production of ferroalloys and master alloys. Moscow: Publishing house of literature on ferrous and nonferrous metallurgy.

[10] Bebbington R. W. (1992). The role of Ferroboron and ferrotitanium in steels: Production methods, quality aspects, and addition techniques, in Proceedings of the 1st International Chromium Steels and Allows Congress. INFACON 6. Johannesburg: SAIMM.

[11] Zhuchkov V.I., Sychev A.V., Akberdin A.A. et al. (2015). Research and improvement of the process of obtaining complex boron-containing ferroalloys. in Proceedings of XVI Int. conference «Modern problems of electrometallurgy of steel and ferroalloys». Chelyabinsk: SUSU Publishing Center.

[12] Zhuchkov V.I., Selivanov E.N., Zayakin O.V et al. (2015). A method of obtaining a complex boron-containing alloy based on silicon. Eurasian patent No. 020687

[13] Zhuchkov V.I., Zayakin O.V., Leont ev L.I. et al. (2017). Physico-chemical characteristics, preparation and use of complex boron-containing ferroalloys. Proceedings of the higher educational institutions. Ferrous metallurgy, vol. 60, no. 5, pp. 348-354.

[14] Sychev A.V., Zhuchkov V.I., Akberdin A.A., Afanasyev V.I. (2015) Study of the processes of stabilization of disintegrating slags of low-carbon ferrochrome boroncontaining materials in Proceedings Works scientific-practical. conf. "Prospects for the development of metallurgy and mechanical engineering with the use of completed basic research and R \& D". Yekaterinburg: The Ural Worker. 